\title{
Salmonella Enteritidis in Layer Farms of Different Sizes Located in Northern China: On-Farm Sampling and Detection by the PCR Method
}

\section{-Author(s)}
Li X
Liu L'
Li Q'
Xu G'

Zheng J'

National Engineering Laboratory for Animal Breeding and MOA Key Laboratory of Animal Genetics and Breeding, College of Animal Science and Technology, China Agricultural University, Beijing 100193, China

\section{nail Address}

Corresponding author e-mail address Jiangxia Zheng

No 2, yuanmingyuan west Road, Haidian district (West campus of China

Agricultural University), Beijing, Beijing, China. Zip Code: 100193

Tel: $\quad$ +861062732741

Email: jxzheng@cau.edu.cn

\section{-Keywords}

Environment, layer farm, PCR, Salmonella Enteritidis.

\section{ABSTRACT}

Salmonella enterica subspecies enterica serotype Enteritidis (SE) has caused foodborne infections over decades. It is transmitted mainly from contaminated eggs to humans. SE is commonly present in layer houses, and closely interacts with environmental factors. The objective of the present study was to develop a viable PCR method to identify $\mathrm{SE}$ in environmental samples collected in layer farms of different sizes, and to evaluate SE contamination status in four main egg-production provinces of northern China. After specificity retrieval using PrimerBLAST against the NCBI database, three SE specific oligonucleotide primers were selected as candidate primers. The primers targeting Prot6e gene were adopted and primers targeting Sdf I were also selected to validate the results, after testing eight different types of pooled poultry environmental samples (overshoe, air, drinking nipple, feed, egg collection belt, eggshell, air inlet, and air outlet) by PCR. A PCR detection limit of $1 \mathrm{CFU} / \mathrm{mL}$ was determined using cell lysates from pure cultures. Testing time was less than $48 \mathrm{~h}$. On-farm samples were collected from two layer farm sizes (one housing more than 50,000 layers, and the other, less than 50,000 layers) in each province. The applied PCR method was shown to be simple, inexpensive and effective for screening SE in a large amount of farm samples. The study identified only one SE-positive farm, which a large farm and where nine samples were found to be contaminated with SE: drinking nipples (3), egg collection belt (1), air inlet (1), air (1), overshoe (1) and eggshell (2).

\section{INTRODUCTION}

The prevalence in humans of the most frequently isolated Salmonella serotype (Gantois et al., 2009), Salmonella enterica serovar Enteritidis (SE), has increased since the late 1960s (Bäumler et al., 2000). Several outbreaks of human SE infection have been reported, and were associated with the consumption of contaminated eggs (Castanheira et al., 1995; Crespo et al., 2005; Much et al., 2009; Vaz et al., 2010; Guo et al., 2015; Zhou et al., 2015). Around $80 \%$ of 371 known SE outbreaks in the United States between 1985 and 1999 were linked to contaminated eggs (Patrick et al., 2004). This pathogen spreads mainly through food production chain, and particularly increases with egg consumption (CDC, 2000; Osimani et al., 2016, Li et al., 2016). Poultry eggs are initially infected with SE inside the layer houses (Guard-Petter, 2001; Dewaele et al., 2012; Ricke et al., 2013). Research indicated that contamination persisted even after effective terminal cleaning and disinfection (C\&D) processes (Carrique-Mas et al., 2009). In addition, asymptomatic infection increases the difficulties in detecting SE infection in poultry flocks (Gast \& Holt, 1998; Guard-Petter, 2001). Although some strategies for reducing SE in the production chain were studied (Ricke et al., 2013; Upadhyaya et al., 2013), particular importance has to be 
given to monitoring and controlling SE contamination in the layer house environment. According to the latest statistics of the Food and Agriculture Organization of the United Nations (FAO), egg production in China has exceeded 24.78 million tons, accounting for about $36.33 \%$ of world's total production. However, few investigations on egg contamination with SE have been carried out in China.

Several methods of SE identification have been evaluated (Oliveira et al., 2002; Moongkarndi et al., 2011; Dewaele et al., 2012). The polymerase chain reaction $(P C R)$ is a well-established technique and has proven to be practical in terms of cost, time, and sensitivity (Almeida et al., 2013), particularly for the detection of a large number of field samples. Although some multiplex PCR systems have been proposed (Trafny et al., 2006; O'Regan et al., 2008; Park et al., 2009; de Freitas et al., 2010), a study reported that they have relatively poor sensitivity (Chen et al., 2012). Multiple primer pairs were later applied, but this significantly increased the probability of producing non-specific bands and even false positive results, especially when the poultry house environment contained countless unknown bacteria communities (Dumas et al., 2011). Real-time PCR method also showed high specificity in SE detection, but the high cost of the detection instruments and test reagents hinders its use for largescale screening (Espy et al., 2006).

In the present study, we first aligned collected primer pairs from previous PCR methodology studies on SE detection with Primer-BLAST against the NCBI database. Based on the results of specificity retrieval, selected candidate primers were tested in pooled poultry environment samples using a general PCR procedure. After adjusting the DNA extraction process and PCR program parameters, the final candidate primer located on Prot6e gene was applied to PCR protocols, and primers targeting $S d f$ / were designed to verify on-farm results. The detection limit was finally determined using 10-fold serially diluted SE bacterium solution. Finally, environmental SE contamination was investigated in four main egg production areas in northern China. In summary, the aim of the present study was to establish a simple, inexpensive, and effective method for SE screening for the surveillance of SE contamination status of laying hen farms.

\section{MATERIALS AND METHODS}

\section{Screening of specific SE primers with Primer-BLAST}

We reviewed 19 papers on SE detection using PCR published between 1994 and 2012. A total of eight primer pairs expected to be SE-specific were chosen from seven representative papers, and the details are shown in Table 1.

Primer-BLAST (http://www.ncbi.nlm.nih.gov/tools/ primer-blast) was used to check the specificity of those eight primers. Default checking parameters remained unchanged, except that Genome (chromosomes from

Table 1 - Oligonucleotide primers used for verifying Salmonella Enteritidis detection

\begin{tabular}{|c|c|c|c|c|c|c|}
\hline Target gene & Primers ${ }^{1)}$ & Sequence $\left(5^{\prime}-3^{\prime}\right)$ & Location & $\begin{array}{l}\text { Amplicon } \\
\text { size (bp) }\end{array}$ & $\begin{array}{l}\text { Accession number } \\
\text { (GenBank) }\end{array}$ & References \\
\hline \multirow{2}{*}{ sefA } & $\begin{array}{l}\text { A058 (F) } \\
\text { A01 (R) }\end{array}$ & $\begin{array}{l}\text { GATACTGCTGAACGTAGAAGG } \\
\text { GCGTAAATCAGCATCTGCAGTAGC }\end{array}$ & $N G^{2)}$ & 488 & 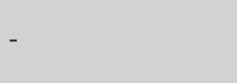 & (Doran et al., 1996) \\
\hline & $\begin{array}{l}\text { Forward (F) } \\
\text { Reverse (R) }\end{array}$ & $\begin{array}{l}\text { GGCTTCGGTATCTGGTGGTGTA } \\
\text { GTCATTAATATTGGCTCCCTGAATA }\end{array}$ & $\begin{array}{l}330-351 \\
402-426\end{array}$ & 97 & L03833 & (Seo et al., 2004) \\
\hline SdfI & $\begin{array}{l}\text { Forward (F) } \\
\text { Reverse (R) }\end{array}$ & $\begin{array}{l}\text { TGTGTTTTATCTGATGCAAGAGG } \\
\text { CGTTCTTCTGGTACTTACGATGAC }\end{array}$ & $\begin{array}{l}23-45 \\
295-351\end{array}$ & 293 & AF370707 & $($ Agron et al., 2001)3) \\
\hline $\begin{array}{l}\text { insertion } \\
\text { element }\end{array}$ & $\begin{array}{l}\text { IE1L (F) } \\
\text { IE1R (R) } \\
\text { IE2L (F) } \\
\text { IE3R (R) }\end{array}$ & $\begin{array}{l}\text { AGTGCCATACTTTTAATGAC } \\
\text { ACTATGTCGATACGGTGGG } \\
\text { GGATAAGGGATCGATAATTGC } \\
\text { GGACTTCCAGTTATAGTAGG }\end{array}$ & $\begin{array}{l}397-416 \\
694-712 \\
610-630 \\
1150-1169\end{array}$ & $\begin{array}{l}316 \\
560\end{array}$ & Z83734 & (Wang and Yeh, 2002) \\
\hline Prot6e & $\begin{array}{l}\text { Prot6e-5 (F) } \\
\text { Prot6e-6 (R) } \\
438(F) \\
572(R)\end{array}$ & $\begin{array}{l}\text { ATATCGTCGTTGCTGCTTCC } \\
\text { CATTGTTCCACCGTCACTTTG } \\
\text { GGCACCGCAGCAATGGTTGG } \\
\text { GGTCGAGCTACAGAGAGTCACAC }\end{array}$ & $\begin{array}{l}387-406 \\
572-592 \\
438-457 \\
550-572\end{array}$ & $\begin{array}{l}206 \\
135\end{array}$ & U66901 & $\begin{array}{l}(\text { Malorny et al., 2007)3) } \\
\text { (Hadjinicolaou et al., 2009) }\end{array}$ \\
\hline invA & $\begin{array}{l}\operatorname{invA-F}(F) \\
\operatorname{invA-B}(R)\end{array}$ & $\begin{array}{l}\text { TCCCTTTGCGAATAACATCC } \\
\text { ATTACTTGTGCCGAAGAGCC }\end{array}$ & NG & 725 & - & (Chen et al., 2012) \\
\hline
\end{tabular}

1) Oligonucleotide primer names were quoted as shown the original papers; Primer orientation is indicated in parenthesis: $F$, forward; $R$, reverse.

2) NG means the location of primer-targeted gene was not given in the reference.

3) Primer pairs of Salmonella Enteritidis finally adopted in this study. 
all organisms) was selected as active-search database. Based on the Primer-BLAST results, three pairs of the SE candidate primer were further tested by PCR using farm samples.

\section{Experimental farm samples and SE culture procedures}

Experimental farm samples were collected from over shoes, house air, drinking nipples, feed, egg collection belt, eggshell, air inlet and air outlet from a layer house of the Experimental Unit for Poultry Genetic Resource and Breeding at China Agricultural University (CAU), and were pooled per sample type.

Samples were firstly placed on a culture plate and homogenized with Buffered Peptone Water (BPW) at $1: 9$ dilution, and incubated at $37^{\circ} \mathrm{C}$ for $18 \mathrm{~h}$ with shaking at $170 \mathrm{rpm}$. Then, $1 \mathrm{~mL}$ of the bacterial solution was transferred to $9 \mathrm{~mL}$ of Selenite Cystine Broth (SC) and incubated at $37^{\circ} \mathrm{C}$ for $18 \mathrm{~h}$ with shaking at 170 rpm.

\section{Genomic DNA extraction}

Genomic DNA extraction process was carried out by transferring $1 \mathrm{~mL}$ of selective enriched sample to a microcentrifuge tube. Cell suspension was centrifuged at $12,000 \mathrm{rpm}$ for $5 \mathrm{~min}$ at $4^{\circ} \mathrm{C}$ in a centrifuge (5424R, Eppendorf ${ }^{\circledR}$, Hamburg, Germany), then the supernatant was discarded. The pellet was washed twice with double-distilled water $\left(\mathrm{ddH}_{2} \mathrm{O}\right)$ taken from a Millipore Milli-Q ${ }^{\circledR}$ Academic Water Purification System (Merck KGaA, Darmstadt, Germany), and washed again in 1-mL anhydrous ethanol suspension. The

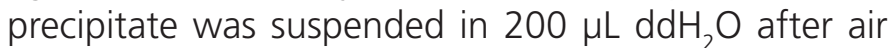
drying. The microcentrifuge tube was then boiled for $15 \mathrm{~min}$ and chilled immediately on ice for $2 \mathrm{~min}$. The tube was centrifuged at $12,000 \mathrm{rpm}$ for $15 \mathrm{~min}$ at $4^{\circ} \mathrm{C}$. Afterwards, the supernatant was transferred to a new microcentrifuge tube and used as DNA template for the PCR.

\section{Selection of candidate primers using Polymerase Chain Reaction}

Amplification of the farm samples was carried out in a total volume of $20 \mu \mathrm{L}$ as follows: $10 \mu \mathrm{L} 2 \times$ Power Taq PCR MasterMix (Bioteke Corporation, Beijing, China) with Taq DNA polymerase, PCR buffer, dNTP mixture containing $\mathrm{Mg}^{2+}, 1 \mu \mathrm{L} 10 \mu \mathrm{M}$ of each primers, 2 $\mu \mathrm{L}$ of extracted DNA template and $6 \mu \mathrm{L}$ of $\mathrm{dd}_{2} \mathrm{O}$. PCR amplification was performed in an Applied Biosystems ${ }^{\circledR}$ Veriti ${ }^{\mathrm{TM}}$ 96-Well Thermal Cycler (Life Technologies, CA, USA) with an initial denaturation at $95^{\circ} \mathrm{C}$ for $5 \mathrm{~min}$, followed by 35 cycles of $95^{\circ} \mathrm{C}$ for $30 \mathrm{~s}, 58^{\circ} \mathrm{C}$ for 30 $\mathrm{s}, 72^{\circ} \mathrm{C}$ for $20 \mathrm{~s}$ and finished with a final extension at $72^{\circ} \mathrm{C}$ for $10 \mathrm{~min}$.

Each PCR assay systematically included positive and negative controls with genomic DNA of SE strains and $\mathrm{ddH}_{2} \mathrm{O}$, respectively. Aliquots $(5 \mu \mathrm{L})$ of the PCR products were analyzed by electrophoresis on 2\% (wt/vol) agarose gels (BIOWEST ${ }^{\circledR}$, Nuaillé, France) using PowerPac ${ }^{\mathrm{TM}}$ Basic Power Supply (BioRad Laboratories, CA, USA), stained with GelStain (Transgen Biotech, Beijing, China), and visualized under

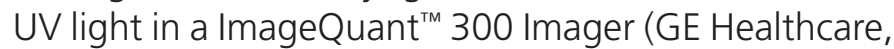
Buckinghamshire, UK).

\section{Determination of SE detection sensitivity}

Optimal PCR annealing temperature was firstly determined. Temperatures of $56^{\circ} \mathrm{C}, 58^{\circ} \mathrm{C}, 60^{\circ} \mathrm{C}$, $62^{\circ} \mathrm{C}, 64^{\circ} \mathrm{C}$, and $66^{\circ} \mathrm{C}$ were set as annealing temperatures along with forward \& reverse Prot6e primers.PCR amplification was performed in triplicate. Amplification efficiency was estimated by calculating the standardized grayscale for each expected band. Grayscale analysis was performed using Image software version 1.50a (The University of Queensland, unknown). Amplification efficiency was calculated as:

$$
A E=\operatorname{Gra}(A P) / G r a(M k)
$$

Where $A E$ is the amplification efficiency at different annealing temperatures, Gra (Ap) is the grayscale of amplicons targeting the Prot6e gene, and Gra (Mk) the $400 \mathrm{bp}$ band derived from Marker 1 (Dongsheng Biotech, Guangdong, China).

Both cell lysate and SE liquid were used as templates to perform PCR amplification for the comparative evaluation of sensitivity. The strains of Salmonella enterica serovar Enteritidis were obtained from the China Institute of Veterinary Drugs Control (IVDC). Detection limit was evaluated using 10-fold dilutions of the reference SE strains. At each dilution step, sufficient amount was saved for PCR analyses. Each dilution was enriched as mentioned above, and the extracted genome or bacterial liquid was used as DNA template for the PCR assay. The plate count method was used to determine CFU. Viable SE amounts were obtained by plating 10-fold serial dilutions of inoculated broth cultures onto nutrient agar thrice and incubating the plates at $37^{\circ} \mathrm{C}$ for $24 \mathrm{~h}$.

Cell lysate amplification was carried out as described in the section of candidate primers selection. For amplification with bacterial liquid, pure SE suspensions were firstly homogenized with an adequate amount of $\mathrm{BPW}$, and incubated overnight at $37^{\circ} \mathrm{C}$ with shaking at 170 rpm for the next step. PCR assay was carried out 
in a total volume of $20 \mu \mathrm{L}$ as follows: $10 \mu \mathrm{L}$ One $\operatorname{Taq}^{\circledR}$ $2 \times$ Master Mix with Standard Buffer (NEW ENGLAND Biolabs $^{\circledR}, \mathrm{MA}$, USA), $0.4 \mu \mathrm{L} 10 \mu \mathrm{M}$ of each primer, $2 \mu \mathrm{L}$ of bacterial liquid, and $7.2 \mu \mathrm{L} \mathrm{ddH_{2 }} \mathrm{O}$. PCR amplification was performed with initial denaturation at $94^{\circ} \mathrm{C}$ for 30 $\mathrm{s}$, followed by 30 cycles of $94^{\circ} \mathrm{C}$ for $30 \mathrm{~s}, 58^{\circ} \mathrm{C}$ for 1 min, $68^{\circ} \mathrm{C}$ for $20 \mathrm{~s}$, and final extension at $68^{\circ} \mathrm{C}$ for $5 \mathrm{~min}$. Agarose gel electrophoresis was proceeded as described in this study.

\section{Environmental contamination of commer- cial farms with SE}

In total, 1512 samples were collected on eight battery-cage commercial farms in the four main eggproduction provinces in a voluntary SE surveillance study carried out in northern China between August and December 2014. Detailed information is shown in Table 2. Two commercial egg-production farm sizes were selected in each province: one housing more than 50,000 layers, and the other, less than 50,000 layers. Layer house and its corresponding egg collection area were randomly chosen as sampling sites in each farm. Feed, drinking nipple, egg collection belt, air inlet, air outlet, air, overshoe, and eggshell were sampled inside each house, and air, overshoes, and eggshells in the egg collecting area. Sampling was carried by scraping or wetting with asterile cotton swab according to the sample type.

Table 2 - Sampled farms from four main egg production areas in the northern China

\begin{tabular}{lcrlcc}
\hline Province & Farm $^{1)}$ & Scale & Layer strain2) & $\begin{array}{c}\text { Housing } \\
\text { system }\end{array}$ & Structure \\
\hline Shandong & A & 30,000 & Hy-Line Brown & & Semi open \\
& B & 50,000 & Hy-Line Brown & & Semi open \\
Liaoning & C & 19,000 & Hy-Line Brown & & Semi open \\
& D & 60,000 & Hy-Line Brown & Battery & Semi open \\
Henan & E & 40,000 & Nongda No.3 & cage & Semi open \\
& F & 250,000 & Nongda No.3 & & Closed \\
Hebei & G & 4,000 & Hy-Line Sonia & Open \\
\hline
\end{tabular}

1) Farms were named alphabetically.

2) Same strain was kept in each sampled layer house.

The sterile cotton swab covered with targeted samples were put in a culture plate with BPW at 1:9 dilution, stored in a cooler box at about $4^{\circ} \mathrm{C}$, and transported to the laboratory, where they were submitted to the detection procedures described above.

\section{Statistical analysis and plotting}

Statistical analyses of annealing temperature determination were executed using SAS version 9.3
(SAS Institute Inc., North Carolina, US). One-way analysis of variance process was applied to examine differences in amplification efficiency at different annealing temperatures. Plotting was accessed using $R$ software with ggpolt2 package, parameters were set according to practical requirements.

\section{RESULTS}

\section{Primer screening via BLAST}

SE primers used in the present study were checked for their specificity by Primer-BLAST. Results showed that the primers shown in Table 1 were capable of detecting Salmonella enterica subspecies enterica serovar Enteritidis, but not all primers excluded other serotypes. The serotypes corresponding to the target genes detected with each primer are shown in Table 3. We listed target genes rather than its original primer pairs, since primers located on the same gene yielded identical specificity results. In summary, primer pairs located on sefA, insertion element and invA genes were able to detect other Salmonella serotypes belonging to Salmonella serogroup $A, B, C$ and $D$ serovars, in addition to Enteritidis, while oligonucleotide primers targeting Sdf I and Prot6e genes identified only Enteritidis. Therefore, three primer pairs located on these two genes were nominated as candidate primers.

Table 3 - Target gene and its specific Salmonella serotypes matched by Primer-BLAST

\begin{tabular}{lccccc}
\hline $\begin{array}{l}\text { Gene target } \\
\text { Serotype }\end{array}$ & SefA & SdfI & $\begin{array}{l}\text { Insertion } \\
\text { element }\end{array}$ & Prot6e & invA \\
\hline Enteritids & $\sqrt{ } 2)$ & $\sqrt{ }$ & $\sqrt{ }$ & $\sqrt{ }$ & $\sqrt{ }$ \\
$\begin{array}{l}\text { Dublin } \\
\text { Pullorum }\end{array}$ & $\sqrt{ }$ & $\sqrt{ }$ & & $\sqrt{ }$ \\
Gallinarum & & & \\
Typhi & $\sqrt{ }$ & & $\sqrt{ }$ \\
Paratyphi A & & & \\
Paratyphi C & & & \\
Typhimurium & & & \\
... & & & \\
\hline
\end{tabular}

1) The symbol " $\sqrt{ }$ " indicates certain Salmonella serotype was detectable by targeted primer pairs.

\section{Specific examination by PCR assay}

After Primer-BLAST alignment, two primer pairs targeting Prot6e gene and an oligonucleotide primer targeting Sdf / gene were shown to be SE-specific. PCR analysis was performed to check the identifiability of these three primers with farm samples. Results showed that non-specific bands between 100 and 600 bp were captured using primer pairs of Prot6e 438 (F) \& 572 $(\mathrm{R})$, while environmental sample lanes were much cleaner, with primers targeting $S d f$ / gene and primer 
pairs of Prot6e 5 (F) \& 6 (R). Eventually, Prot6e 5 (F) \& $6(R)$ were chosen for further SE screening, considering experimental results by Malorny et al. (2007), and another SE-specific marker targeting $\mathrm{Sdf}$ / was selected to screen all the environmental samples.

\section{Detection sensitivity of the PCR assay}

Relative to the detection sensitivity of the primers Prot6e $5(\mathrm{~F})$ \& $6(\mathrm{R})$, band intensity of the target amplicons was reduced as annealing temperature was gradually increased. Standardized band intensities of the target amplicons were not considerably different at $56^{\circ} \mathrm{C}$ and $58^{\circ} \mathrm{C}$ (Figure 1). Band intensities sharply decrease dat temperatures higher than $58^{\circ} \mathrm{C}$, and were significantly lower compared with those obtained at $56^{\circ} \mathrm{C}$ and $58^{\circ} \mathrm{C}(p<0.0001)$. Therefore, the optimal annealing temperature suggested was $58^{\circ} \mathrm{C}$.

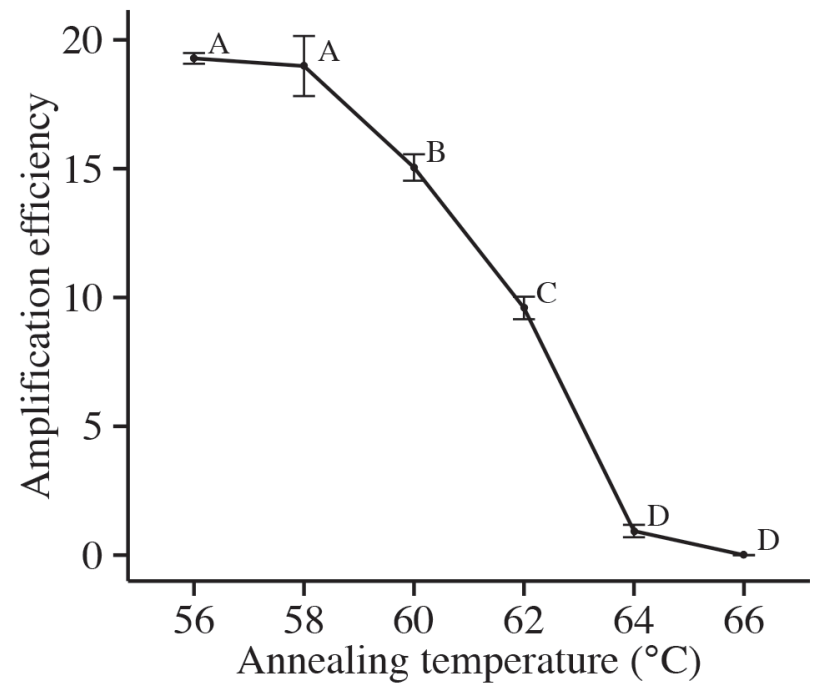

Figure 1 - Amplification efficiency of the adopted Prot6e primers at different annealing temperatures. Amplification efficiency was estimated based on the standardized production of the amplicon, which was calculated as the grayscale value of the targeted band divided by that of indicating marker. Higher values indicate superior amplification efficiency. Common letters beside each solid point indicate no significant differences ( $p<$ 0.05). Vertical bars denote standard deviation (SD) within each group.

Simultaneously to PCR sensitivity calculations, a comparative evaluation of sensitivity was also made using amplifications of bacterial cell suspensions. A detection limit of $1 \mathrm{CFU} / \mathrm{mL}$ was obtained after the general SE identification procedure with dilutions of the reference SE strains (Figure 2A), which was more sensitive than the direct amplification of the SE suspensions. The PCR sensitivity using bacterial liquid was about $800 \mathrm{CFU} / \mathrm{mL}$ (approximately as low as 8 CFU per $\mathrm{PCR}$ reaction), as shown in Figure $2 \mathrm{~B}$. In addition, lane 1 in Figure $2 \mathrm{~B}$ was inverted and enhanced for better identification resolution (Figure $2 \mathrm{C}$ ).

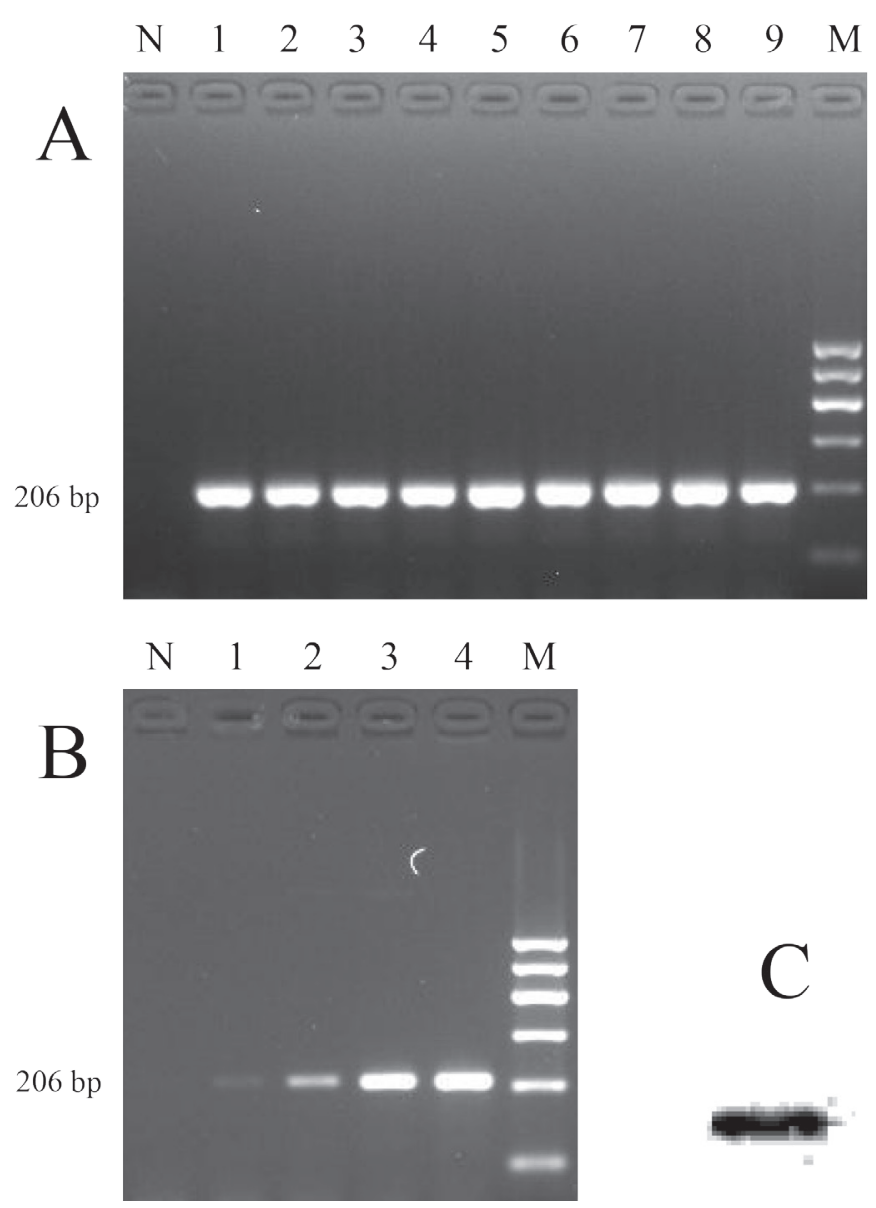

Figure 2 - Sensitivity of PCR identification of Salmonella Enteritidis. The detection limit was determined using 10-fold dilutions of the reference strains. CFU level was measured using the plate count method. Lane N: negative control, lane M: Maker 1. (A). Detection limit with of extracted DNA templates after enrichment procedures. Lanes 1-9: $10^{2} \mathrm{CFU} / \mathrm{L}$ to $10^{10} \mathrm{CFU} / \mathrm{L}$. (B). Detection limit with bacterial liquid templates. Lanes 1-4: $8 \times 10^{5} \mathrm{CFU} / \mathrm{L}$ to $8 \times 10^{8} \mathrm{CFU} / \mathrm{L}$. (C). Processed band of lane 1 in Figure $2 \mathrm{~B}$ with ImageJ software.

\section{Environmental contamination of SE on layer farms}

According to the Prot6e 5 (F) \& 6 (R) results, non-contaminated samples were confirmed as SEnegative by $S d f$ I primer pairs in seven of the eight farms evaluated. Only samples from farm $\mathrm{H}$ were contaminated with Salmonella Enteritidis (Table 4). The contamination rates of the different sample types varied between $3.7 \%$ and $16.7 \%$, with a total contamination prevalence of SE-positive samples of $4.8 \%$. In the layer house, contamination was detected in three water samples collected from the drinking nipples, which were located on different pipelines and distant from each other. An egg collection belt sample was positive for SE at the bottom tier, near the air inlet. One sample spot on the top of the air inlet and one overshoe swab sample of the left foot were also contaminated. In the egg collecting area, only two eggshell samples were detected as positive for SE. 
Table 4 - Salmonella Enteritidis contamination of samples collected in layer farms in northern China

\begin{tabular}{|c|c|c|c|}
\hline \multirow[t]{2}{*}{ Location } & & \multicolumn{2}{|c|}{$\begin{array}{c}\text { Contaminated samples/ } \\
\text { Examined samples }\end{array}$} \\
\hline & & Farm A - Farm G & Farm H \\
\hline \multirow{8}{*}{ Henhouse } & Feed & \multirow{12}{*}{ ND ${ }^{1)}$} & $0 / 27$ \\
\hline & Drinking nipple & & $3 / 27$ \\
\hline & Egg collection belt & & $1 / 27$ \\
\hline & Air inlet & & $1 / 9$ \\
\hline & Air outlet & & $0 / 9$ \\
\hline & Air & & $1 / 9$ \\
\hline & Overshoe & & $1 / 6$ \\
\hline & Eggshell & & $0 / 30$ \\
\hline \multirow{3}{*}{ Egg collecting area } & Air & & $0 / 9$ \\
\hline & Overshoe & & $0 / 6$ \\
\hline & Eggshell & & $2 / 30$ \\
\hline Total percentage & & & $4.8 \%$ \\
\hline
\end{tabular}

1) Contamination of Salmonella Enteritids was not detected in tested samples.

\section{DISCUSSION}

PCR is an efficient method for screening SE contamination in poultry environmental samples, considering factors such as cost, time, and accuracy. It is well known that primer-targeted sequences can influence PCR specificity (Seo et al., 2004). Salmonella serovars are extremely similar within conserved regions even with other bacterial species like Escherichia coli (E. coli), and therefore, it is essential to select the appropriate oligonucleotide primers for subsequent identification process (Boyd et al., 1996; McClelland et al., 2001; Edwards et al., 2002). Unlike other primer design software programs, Primer-BLAST is an online tool that allows checking the specificity checking of pre-existing primers. It combines the BLAST program with the Needleman-Wunsch (NW) global alignment algorithm to ensure full alignments, and this strategy is sufficiently sensitive to identify targets that differ from the original primers (Needleman \& Wunsch, 1970; Ye et al., 2012). Using the giant and burgeoning database owned by NCBI, primer specificity tests are faster and more accurate. In the present study, three candidate primer pairs were targeted after sequence alignment via Primer-BLAST. After further testing of farm samples with PCR, the Prot6e-5 (F) \& Prot6e-6 (R) primers located on Prot6e gene were eventually adopted. This gene may play a role in biosynthesis of the surface fimbriae and alter their interaction with egg albumen components (Clavijo et al., 2006). Malorny et al. (2007) tested a panel of 119 non-Enteritidis SE strains comprising 54 serovars, as well as 79 SE strains comprising 19 different phage types, and verified that none of these non-Enteritidis strains were positive for the Prot6e gene. Moreover, those researchers found that nearly all SE strains analyzed presented a specific $60-\mathrm{kb}$ virulence plasmid, and inferred that plasmidfree strains were less virulent. Although chromosomallocated fragment gene $\mathrm{Sdf} /$ also showed high exclusivity, which was employed to confirm the detection results in the present study, phage types 6A, 9A, 11, 16, 20, and 27 did not present such gene (Agron et al., 2001).

The pre-enrichment and selective enrichment steps before the PCR assay were performed to dilute PCRinhibitory substances as well as to improve detection sensitivity, and proved to be more sensitive than the traditional culture method and direct amplification (Hsu et al., 2011). Both enrichment steps may effectively dilute PCR inhibitors present in environmental matrix. The overnight pre-enrichment step increases the number of intact bacterial cells, and the selective enrichment step suppresses the growth of background flora (O'Regan et al., 2008). The testing procedure was based on thermal-lysed cell DNA extraction method (Wang et al., 1996; Theron et al., 2001; Fan et al., 2014). Double washing steps with $\mathrm{dd}_{2} \mathrm{O}$ prior to DNA extraction and the subsequent washing step with anhydrous ethanol were adopted as part of the process. Hyeon et al. (2010) reported that enrichment media residue still exerted inhibitory effects after a single washing step, while significant improvement in SE detection was observed after an additional washing step. Ethyl alcohol removes water-insoluble inhibitory substances remaining in the matrix. The sensitivity test in this study was conducted using cell lysates from pure cultures, and therefore, the actual detection sensitivity may be a little higher when screening samples from various sorts of environments.

In the conventional PCR assay, high annealing temperature guarantees detection specificity. However, amplification efficiency simultaneously decreases (Rychlik et al., 1990; Shen et al., 2007). The adopted annealing temperature of $58^{\circ} \mathrm{C}$ determined in the preliminary experiment prevented nonspecific reactions, and maintained detection sensitivity. An alternative to increase PCR efficiency without losing its specificity requires using amplification facilitators (Szmolka et al., 2006). The use of bovine thrombin (BT) as an additive in PCR enhances its efficiency and specificity (Zhang et al., 2014), as it has the remarkable ability of effectively reducing PCR inhibition even at nanoscale sizes. Another approach involves the replacement of conventional Taq DNA polymerase. 
A novel Taq DNA polymerase mutant (SD DNA polymerase) produces better PCR amplification results with a DNA template of complex secondary structure or a GC-rich template (Ignatov et al., 2014). As for the electrophoretic-gel processing step shown in Figure 2C, a Java-based software of ImageJ allowed adjusting gel images to a higher discrimination capacity by human eyes (Schneider et al., 2012).

Northern China is the main egg production region of that country. The annual report of the National Bureau of Statistics of the People's Republic of China (NBS) showed that the egg production of Henan, Shandong, Hebei, and Liaoning provinces accounted for half of the countrywide capacity in 2014 (National Bureau of Statistics of China, 2015). Another survey conducted by the National Laying Hen Industrial Technology System showed that most layer farms, up to $88.28 \%$, housed 2,000 to 50,000 laying hens, and small-household farming systems produce most of the eggs. In the present study, on-farm surveillance was conducted to evaluate the SE-contamination status of layer farms of two different scales. No SE contamination was found in small household farms, and the only contaminated samples were collected on a single large-scale layer farm. SE outbreaks are rarely reported in China, which maybe partly due to Chinese dietary habit of eating only cooked eggs. Contamination of SE is ubiquitous in different housing systems (Holt et al., 2011), and we focused the study on the battery-cage systems, which are predominant in many regions of China. Cloacal and fecal samples were not collected due to intermittent SE excretion by infected hens (Gast et al., 2015). On the SE-positive farm, contaminated water samples were collected from drinking nipples scattered on different pipelines, which indicates that SE may not originate from the water reservoir, whereas the physical structure of the drinking nipple may effectively prevent the ascending contamination of pathogenic bacteria. Airborne transmission route is one of the SE propagation paths, and accordingly, contamination was also found in an air sample. Se-positive samples collected from eggshells in the egg collecting area highlight the necessity of disinfection and sterilization during the transport of poultry eggs. In a previous study, Dewaele et al. (2012) observed persistent SE contamination of the environment during the entire laying period. Interestingly, on farm $\mathrm{H}$, all Salmonella-positive samples were contaminated with SE (Li X. Z., 2016, unpublished data), demonstrating the competitive exclusion between SE and other Salmonella serotypes to some extent (Rabsch et al., 2000). Due to the governmental enforcement and to the objectives of "establishing standardized poultry farms, disease decontamination, and biosecurity measures" by the egg industry, strict self-discipline is exercised in layer farms. The results of the present study indicate that the established normative control measures and disease control and prevention systems have effectively inhibited the dissemination of SE in the farm environment in China, independently of farm scale.

\section{CONCLUSION}

The PCR method applied for screening SE in farm samples is simple, inexpensive, as well as effective. Using the specific single-primer PCR method, minor environmental contamination with Salmonella Enteritidis was detected on layer farms in northern China. Several areas within layer farms may contribute for SE dissemination.

\section{ACKNOWLEDGEMENTS}

The work was partially funded by the Special Fund for Agro-scientific Research in the Public Interest (201303084) and China Agriculture Research Systems (CARS-41)

\section{REFERENCES}

Agron PG, Walker RL, Kinde H, Sawyer SJ, Hayes DC, Wollard J, et al. Identification by subtractive hybridization of sequences specific for Salmonella enterica serovar Enteritidis. Applied and Environmental Microbiology 2001;67(11):4984-4991.

Almeida C, Cerqueira L, Azevedo N, Vieira M. Detection of Salmonella enterica serovar Enteritidis using real time PCR, immunocapture assay, PNA FISH and standard culture methods in different types of food samples. International Journal of Food Microbiology 2013;161(1):1622.

Bäumler AJ, Hargis BM, Tsolis RM. Tracing the origins of Salmonella outbreaks. Science 2000;287(5450):50-52

Boyd EF, Wang F-S, Whittam TS, Selander RK. Molecular genetic relationships of the salmonellae. Applied and Environmental Microbiology 1996;62(3):804-808.

Carrique-Mas JJ, Marín C, Breslin M, McLaren I, Davies R. A comparison of the efficacy of cleaning and disinfection methods in eliminating Salmonella spp. from commercial egg laying houses. Avian Pathology 2009;38(5):419-424.

Castanheira G, Irino K, Gelli D. Surto alimentar por Salmonella enteritidis no noroeste do estado de São Paulo, Brasil. Revista de Saúde Publica $1995 ; 29(2): 127-131$.

Chen J, Tang J, Liu J, Cai Z, Bai X. Development and evaluation of a multiplex PCR for simultaneous detection of five foodborne pathogens. Journal of Applied Microbiology 2012;112(4):823-830.

Clavijo RI, Loui C, Andersen GL, Riley LW, Lu S. Identification of genes associated with survival of Salmonella enterica serovar Enteritidis 


\section{Salmonella Enteritidis in Layer Farms of Different Sizes Located in Northern China: On-Farm Sampling and Detection by the PCR Method}

in chicken egg albumen. Applied and Environmental Microbiology 2006;72(2):1055-1064.

CDC. Outbreaks of Salmonella serotype enteritidis infection associated with eating raw or undercooked shell eggs--United States, 1996-1998. MMWR. Morbidity and Mortality Weekly Report 2000;49(4):73.

Crespo PS, Hernández G, Echeíta A, Torres A, Ordóñez P, Aladueña A. Surveillance of foodborne disease outbreaks associated with consumption of eggs and egg products: Spain, 2002-2003. Euro Surveillance 2005;10:E050616.

Freitas CG, Santana ÂP, da Silva PHC, Gonçalves VSP, Barros MdAF, Torres FAG, et al. PCR multiplex for detection of Salmonella Enteritidis, Typhi and Typhimurium and occurrence in poultry meat. International Journal of Food Microbiology 2010;139(1):15-22.

Dewaele I, Van Meirhaeghe H, Rasschaert G, Vanrobaeys M, De Graef E, Herman L, et al. Persistent Salmonella Enteritidis environmental contamination on layer farms in the context of an implemented national control program with obligatory vaccination. Poultry Science 2012;91(2):282-291

Doran JL, Collinson KS, Clouthier SC, Cebula TA, Koch WH, Burian J, et al. Diagnostic potential of sefA DNA probes to Salmonella enteritidis and certain other O-serogroup D1 Salmonella serovars. Molecular and Cellular Probes 1996;10(4):233-246

Dumas MD, Polson SW, Ritter D, Ravel J, Gelb Jr J, Morgan R, et al. Impacts of poultry house environment on poultry litter bacterial community composition. PloS One 2011;6(9):e24785.

Edwards RA, Olsen GJ, Maloy SR. Comparative genomics of closely related salmonellae. Trends in Microbiology 2002;10(2):94-99.

Espy $M$, Uhl J, Sloan L, Buckwalter S, Jones M, Vetter $E$, et al. Real-time PCR in clinical microbiology: applications for routine laboratory testing. Clinical Microbiology Reviews 2006;19(1):165-256.

Fan S, Zheng J, Duan Z, Yang N, Xu G. The influences of SE infection on layers' production performance, egg quality and blood biochemical indicators. Journal of Animal Science and Biotechnology 2014;5(1):1.

Gantois I, Ducatelle R, Pasmans F, Haesebrouck F, Gast R, Humphrey TJ, et al. Mechanisms of egg contamination by Salmonella Enteritidis. FEMS Microbiology Reviews 2009;33(4):718-38

Gast RK, Guraya R, Jones DR, Anderson KE. Persistence of fecal shedding of Salmonella Enteritidis by experimentally infected laying hens housed in conventional or enriched cages. Poultry Science 2015;94(7):16501656.

Gast RK, Holt PS. Persistence of Salmonella enteritidis from one day of age until maturity in experimentally infected layer chickens. Poultry Science 1998;77(12):1759-1762

Guard-Petter J. The chicken, the egg and Salmonella enteritidis. Environmental Microbiology 2001;3(7):421-430.

Guo Z, Su Ch, Huang J, Niu J. A Food-Borne Outbreak of Gastroenteritis Caused by Different Salmonella Serotypes in 2 Universities in Xiamen, Fujian, China, in 2012. Japanese Journal of Infectious Diseases 2015;68(3):187-191.

Hadjinicolaou AV, Demetriou VL, Emmanuel MA, Kakoyiannis CK, Kostrikis LG. Molecular beacon-based real-time PCR detection of primary isolates of Salmonella Typhimurium and Salmonella Enteritidis in environmental and clinical samples. BMC Microbiology 2009;9(1):1.

Holt P, Davies R, Dewulf J, Gast R, Huwe J, Jones D, et al. The impact of different housing systems on egg safety and quality. Poultry Science 2011;90(1):251-262
Hsu B-M, Huang K-H, Huang S-W, Tseng K-C, Su M-J, Lin W-C, et al. Evaluation of different analysis and identification methods for Salmonella detection in surface drinking water sources. Science of the Total Environment 2011;409(20):4435-4441.

Hyeon J-Y, Hwang I-G, Kwak H-S, Park C, Choi I-S, Seo K-H. Evaluation of PCR inhibitory effect of enrichment broths and comparison of DNA extraction methods for detection of Salmonella Enteritidis using realtime PCR assay. Journal of Veterinary Science 2010;11(2):143-149.

Ignatov $\mathrm{KB}$, Barsova EV, Fradkov AF, Blagodatskikh KA, Kramarova TV, Kramarov VM. A strong strand displacement activity of thermostable DNA polymerase markedly improves the results of DNA amplification. Biotechniques 2014;57(2):81-87.

Li F, Li F, Chen B, Zhou B, Yu P, Yu S, et al. Sextuplex PCR combined with immunomagnetic separation and PMA treatment for rapid detection and specific identification of viable Salmonella spp., Salmonella enterica serovars Paratyphi B, Salmonella Typhimurium, and Salmonella Enteritidis in raw meat. Food Control 2017;73:587-594.

Malorny B, Bunge C, Helmuth R. A real-time PCR for the detection of Salmonella Enteritidis in poultry meat and consumption eggs. Journal of Microbiological Methods 2007;70(2):245-251.

McClelland M, Sanderson KE, Spieth J, Clifton SW, Latreille P, Courtney $\mathrm{L}$, et al. Complete genome sequence of Salmonella enterica serovar Typhimurium LT2. Nature 2001;413(6858):852-856.

Moongkarndi $\mathrm{P}_{1}$ Rodpai $\mathrm{E}$, Kanarat S. Evaluation of an immunochromatographic assay for rapid detection of Salmonella enterica serovars Typhimurium and Enteritidis. Journal of Veterinary Diagnostic Investigation 2011;23(4):797-801

Much P, Pichler J, Kasper S, Lassnig H, Kornschober C, Buchner A, et al. A foodborne outbreak of Salmonella Enteritidis phage type 6 in Austria, 2008. Wiener Klinische Wochenschrift 2009;121(3-4):132-136.

National Bureau of Statistics of China, 2015. Indicators/agriculture/output of livestock products/output of poultry eggs \& region/national total. 2015. [cited 2016 Jan 6]. Available from: http://data.stats.gov.cn/ english/easyquery.htm?cn=E0103.

Needleman SB, Wunsch CD. A general method applicable to the search for similarities in the amino acid sequence of two proteins. Journal of Molecular Biology 1970;48(3):443-453

O'Regan E, McCabe E, Burgess C, McGuinness S, Barry T, Duffy G, et al. Development of a real-time multiplex PCR assay for the detection of multiple Salmonella serotypes in chicken samples. BMC Microbiology 2008;8(1):1.

Oliveira S, Santos L, Schuch D, Silva A, Salle C, Canal C. Detection and identification of salmonellas from poultry-related samples by PCR. Veterinary Microbiology 2002;87(1):25-35

Osimani A, Aquilanti L, Clementi F. Salmonellosis associated with mass catering: a survey of European Union cases over a 15-year period. Epidemiol Infect 2016:1-13.

Park SH, Kim HJ, Cho WH, Kim JH, Oh MH, Kim SH, et al. Identification of Salmonella enterica subspecies I, Salmonella enterica serovars Typhimurium, Enteritidis and Typhi using multiplex PCR. FEMS Microbiology Letters 2009;301(1):137-146.

Patrick ME, Adcock PM, Gomez TM, Altekruse SF, Holland BH, Tauxe RV, et al. Salmonella Enteritidis infections, United States, 1985-1999. Emerging Infectious Diseases 2004;10(1):1-7.

Rabsch W, Hargis BM, Tsolis RM, Kingsley RA, Hinz K-H, Tschäpe $H$, et al. Competitive exclusion of Salmonella enteritidis by Salmonella gallinarum in poultry. Emerging Infectious Diseases 2000;6(5):443. 
Li X, Liu L, Li Q,

Xu G, Zheng J
Salmonella Enteritidis in Layer Farms of Different Sizes Located in Northern China: On-Farm Sampling and Detection by the PCR Method
Ricke S, Dunkley C, Durant J. A review on development of novel strategies for controlling Salmonella Enteritidis colonization in laying hens: fiberbased molt diets. Poultry Science 2013;92(2):502-525.

Rychlik W, Spencer W, Rhoads R. Optimization of the annealing temperature for DNA amplification in vitro. Nucleic Acids Research 1990;18(21):6409-6412

Schneider CA, Rasband WS, Eliceiri KW. NIH Image to ImageJ: 25 years of image analysis. Nat methods 2012;9(7):671-675.

Seo K, Valentin-Bon I, Brackett R, Holt P. Rapid, specific detection of Salmonella Enteritidis in pooled eggs by real-time PCR. Journal of Food Protection 2004;67(5):864-869.

Shen L, Guo Y, Chen X, Ahmed S, Issa J. Optimizing annealing temperature overcomes bias in bisulfite PCR methylation analysis. Biotechniques 2007;42(1):48.

Szmolka A, Kaszanyitzky É, Nagy B. Improved diagnostic and real-time $P C R$ in rapid screening for Salmonella in the poultry food chain. Acta Veterinaria Hungarica 2006;54(3):297-312.

The University of Queensland. Using image to quantify blots; 2015. [cited 2017 Mar 2]. Available from: http://www.di.uq.edu.au/ sparqimagejblots.

Theron J, Morar D, Du Preez M, Brözel V, Venter S. A sensitive seminested PCR method for the detection of Shigella in spiked environmental water samples. Water Research 2001;35(4):869-874.

Trafny E, Kozłowska K, Szpakowska M. A novel multiplex PCR assay for the detection of Salmonella enterica serovar Enteritidis in human faeces. Letters in Applied Microbiology 2006;43(6):673-679.
Upadhyaya I, Upadhyay A, Kollanoor-Johny A, Baskaran SA, Mooyottu S Darre MJ, et al. Rapid inactivation of Salmonella Enteritidis on shell eggs by plant-derived antimicrobials. Poultry Science 2013;92(12):32283235 .

Vaz C, Streck A, Michael G, Marks F, Rodrigues D, Dos Reis E, et al. Antimicrobial resistance and subtyping of Salmonella enterica subspecies enterica serovar Enteritidis isolated from human outbreaks and poultry in southern Brazil. Poultry Science 2010;89(7):1530-1536.

Wang R-F, Cao W-W, Cerniglia CE. PCR detection and quantitation of predominant anaerobic bacteria in human and animal fecal samples. Applied and Environmental Microbiology 1996;62(4):1242-1247.

Wang SJ, Yeh DB. Designing of polymerase chain reaction primers for the detection of Salmonella enteritidis in foods and faecal samples. Letters in Applied Microbiology 2002;34(6):422-427.

Ye J, Coulouris G, Zaretskaya I, Cutcutache I, Rozen S, Madden TL. PrimerBLAST: a tool to design target-specific primers for polymerase chain reaction. BMC Bioinformatics 2012;13(1):1.

Zhang Y, Li X, Zou R, Xue Y, Lou X, He M. Bovine thrombin enhances the efficiency and specificity of polymerase chain reaction. Biotechniques 2014;57(6):289-294.

Zhou X, He S, Song Q, Zhuang X, Wang Y, Huang $X$, et al. Phenotypic and Genotypic Characterization of Salmonella enterica Serovar Enteritidis Isolates Associated with a Mousse Cake-Related Outbreak of Gastroenteritis in Ningbo, China. Foodborne Pathogens and Disease $2015 ; 12(5): 433-440$. 
